\title{
Developmental Changes in the Historical and Present-Day Trophic Status of Brown Water Lakes. Are Humic Water Bodies a Uniform Aquatic Ecosystem?
}

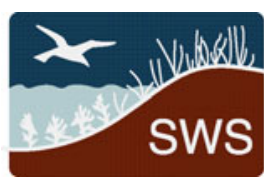

\author{
Danuta Drzymulska $\cdot$ Piotr Zieliński
}

Received: 20 November 2012 / Accepted: 26 June 2013 / Published online: 20 July 2013

(C) The Author(s) 2013. This article is published with open access at Springerlink.com

\begin{abstract}
The long-term development of three humic lake ecosystems in Poland was investigated through palaeoecological analyses of sediment cores. These wetland records spanning the Holocene were analyzed for plant macroremains, degree of peat decomposition, sediment geochemistry along with radiocarbon dating. Morphological characteristics of the catchments and data on contemporary water quality and management approaches were integrated. Our research on the palaeoecology of humic lakes suggests two main states: humic and eutrophic-humic. Of the lakes studied, only one consistently presented features typical of the humic type. The other two showed various states, and dynamic patterns of transformation. The results indicate that these systems can change from humic to eutrophic-humic, and back again, in response to catchment-linked factors, climatic change and human impact. Thus determination of uniform pattern in the development of humic lakes is questionable. This suggests that a reassessment of brown water lakes is necessary.
\end{abstract}

Keywords Humic lake · Sediments · Peat · Subfossil vegetation $\cdot$ Trophy $\cdot$ Catchment

\section{Introduction}

Lakes have been classified according to trophic status since the early twentieth century, when clearwater and dystrophic lakes were distinguished (Nauman 1917; Thienemann 1922).

\footnotetext{
D. Drzymulska $(\triangle)$

Department of Botany, Institute of Biology, University of Białystok, Świerkowa 20b, 15-950 Białystok, Poland

e-mail:drzym@uwb.edu.pl

P. Zieliński

Department of Hydrobiology, Institute of Biology, University of Białystok, Świerkowa 20b, 15-950 Białystok, Poland

e-mail: p.zielinski@uwb.edu.pl
}

Nauman (1917) singled out dystrophic water bodies as those with $d y$ sediments and brown-coloured water. Afterwards these were renamed by Thienemann (1922) as humic lakes. Contrary to clearwater oligo-, meso-, and eutrophic lakes, which can naturally shift from one form to another (Vollenweider 1970; Wetzel 1983), brown water lakes are considered as more uniform. Nevertheless, the origin of both clearwater and humic lakes is usually oligotrophic water in character (Nauman 1919; Davydova and Servant-Vildary 1996).

The terminology related to humic lakes is incongruous and can lead to confusion (Wetzel 1983; Jones 1992), therefore it is essential to develop an unambiguous nomenclature. For example, even the very term dystrophy is controversial, because it suggests only the lack of nutrients in lakes (Hansen 1962), while the lack of nutrients is also linked with a higher amount of humic substances (HS), giving brown water color and low $\mathrm{pH}$ (4.0 6.0). The other characteristic features of humic lakes include peat-covered catchment area, sometimes overgrown with coniferous forests, peat mosses in the vicinity of water bodies, spreading floating mats on water surfaces, low water and sediment calcium content, $d y$ sediments, small algal biomass, poor taxonomic biodiversity, and higher respiration than primary production (Miles and Brezonik 1981; Salonen et al. 1983; Wetzel 1983; Hessen and Tranvik 1998; Górniak et al. 1999; Brönmark and Hansson 2005; Gąbka and Owsianny 2006; Poniewozik et al. 2011; Rodriguéz et al. 2011). Large amounts of humus flow into lakes from catchment basins (De Haan 1992; Hessen 1992), causing water acidification (Kullberg et al. 1993). Organic carbon accretion in humic lake sediments exceeds the areal sequestration rates of soils and forests (Molot and Dillon 1996). The trophic status of humic lakes is determined by vegetation in the catchment and by presence of mires in the vicinity of the lakes. Existence of both the humic lake and the wetland is mutually related and shaped by a complex of biogeochemical processes (Fenner and Freeman 2013). Optimum conditions for forming of these lakes occur in northern regions of the world, with a cool, humid climate 
(Salonen et al. 1983; Kankaala et al. 2006). Among humic lakes those from Northern America and Europe are the most extensively studied featuring in numerous scientific monographs (Hessen and Tranvik 1998; Findlay and Sinsabaugh 2003; Steinberg 2003).

Despite the fact that humic lakes are well described in the literature, most of the research addresses the current status of these water bodies, stressing their hydrobiological, microbiological and ecological problems, like carbon leaching from the catchment and its metabolism in lake (Sachse et al. 2001; Klavins et al. 2003; Taipale et al. 2007), primary production (Jasser 1997; Nürnberg and Show 1998), microbiological utilization of organic matter (Satoh and Abe 1987), and character of vegetation (Catling et al. 1985; Keskitalo et al. 1998). Less attention was paid to historical development of humic lakes. Characteristically, they have been described by some authors as minimally changeable in time (Więckowski 1978; Górniak 1996). On the other hand, humic lakes are considered to be sensitive to environmental disturbances (Curtis 1998), which are especially important in an era of progressive climatic, anthropogenic, hydrometeorological, and ecological changes. In this situation a question is how much sensitive they are.

Climate change models predict that higher temperatures are likely to occur over most of the boreal forests in North America, Europe, and Asia (Porcal et al. 2009) which can cause modifications in habitats making them less favorable for dystrophy and leading to disappearance of humic lakes. Simultaneously, over the past few decades, phenomena that are advantageous for the formation of humic lakes have been observed; namely, the intense export of organic matter to surface waters (Freeman et al. 2001; Roulet and Moore 2006; Evans et al. 2012).

As changes in character of humic lakes are observed now, it is most probable that these water bodies were changing also in the past. In our studies we used palaeobotanical and chemical sediment analyses combined with analyses of current water quality to describe the development of three humic lakes. This made possible to verify views on the functioning of this type of ecosystems. Subfossil plant remains, preserved very well in mires due to their anoxic conditions, render it possible to describe histories spanning thousands of years in lakes surrounded by mires. No such possibility exists for the vicinity of clearwater lakes. One of the most meaningful parameters is sediment $\mathrm{C} / \mathrm{N}$ ratio which allowed determining the sources of organic matter in sediments (autogenic or allogenic).

The aims of the study were: (i) to reconstruct the lakeside vegetation and habitat conditions in the vicinity of the studied water bodies; (ii) to determine whether or not different types of humic lakes occur; (iii) to identify developmental tendencies of humic lakes. Our findings were then used to verify the hypothesis that humic lakes are not uniform ecosystems and can change over time.

\section{Methods}

Study Site and Field Work

Wigry National Park (WNP) is located in NE Poland (Fig. 1). Two physical-geographical mesoregions - the East Suwałki Lakeland and the Augustów Upland, occur in this part of Poland, and both are included in the Lithuanian Lakeland (Kondracki 1994). The terrain of this area was shaped during the Pomeranian phase of the main stadial of the Weichselian (Vistulian) Glaciation (Marks 2002). A number of kames, eskers, and frontal moraine heights occur in the northern and middle parts of WNP, while the southern part of the park comprises an extensive sandur with strongly transformed primary glacial relief (Ber 2009). The climate of this area is temperate, transitional between maritime and continental with a tendency toward continentality. Climatic conditions and vegetation cover liken this territory to Scandinavia.

The humic lakes of the WNP are located in the vicinity of the Wigry Lake, one of the biggest and deepest lakes in Poland (area $21.63 \mathrm{~km}^{2}$, max depth $74.2 \mathrm{~m}$ ). Lake Suchar IV (SIV in following text) and Lake Wądołek (Wd in following text) are located to the north of Lake Wigry, and Lake Sucharek (Sch in following text) is situated on the southern shores of Lake Wigry (Fig. 1). Studied lakes are characterized by different morphological parameters of lake basin and character of catchment (Table 1).

Material for the study was collected from the lakesides of three dystrophic lakes, using a Russian sampler $(50 \mathrm{~cm}$ long and $8 \mathrm{~cm}$ in diameter). The lengths of the cores were as follow: from SIV $-370 \mathrm{~cm}$, from $\mathrm{Wd}-240 \mathrm{~cm}$, and from $\mathrm{Sch}-170 \mathrm{~cm}$. The cores were divided into segments of $5 \mathrm{~cm}$.

\section{Laboratory Analyses}

Macroscopic plant remains analysis was the main method of research. Distilled water with an addition of $10 \% \mathrm{KOH}$, was used to soak the material. Next, the suspensions were boiled, rinsed in a $0.2 \mathrm{~mm}$ sieve, and placed in Petri dishes. At first, generative finds (fruits, seeds, fruit scales) from every sample were picked out. These finds were identified using a stereoscopic binocular microscope (Nikon SMZ 800) at magnification of 10-63×. Vegetative plant remains (roots, epiderm, periderm, rhizoderm, leaves, stems, and wood) were identified using a Leica DM 3000 light miscroscope with 200-400× magnification. Botanical composition, based on a proportion of each taxon tissues in total tissue mass, was estimated. Only remains with cellular structures were taken into account. Remains were identified with help of Mauquoy and van Geel (2007), Hedenäs (2003), Katz et al. (1965), and the collection of macroscopic plant remains at the Institute of Biology, University of Białystok. Countable remains (for example, seeds) were presented at absolute sums. Diagrams of vegetative 
Fig. 1 The location of study lakes in the Wigry National Park (NE Poland)
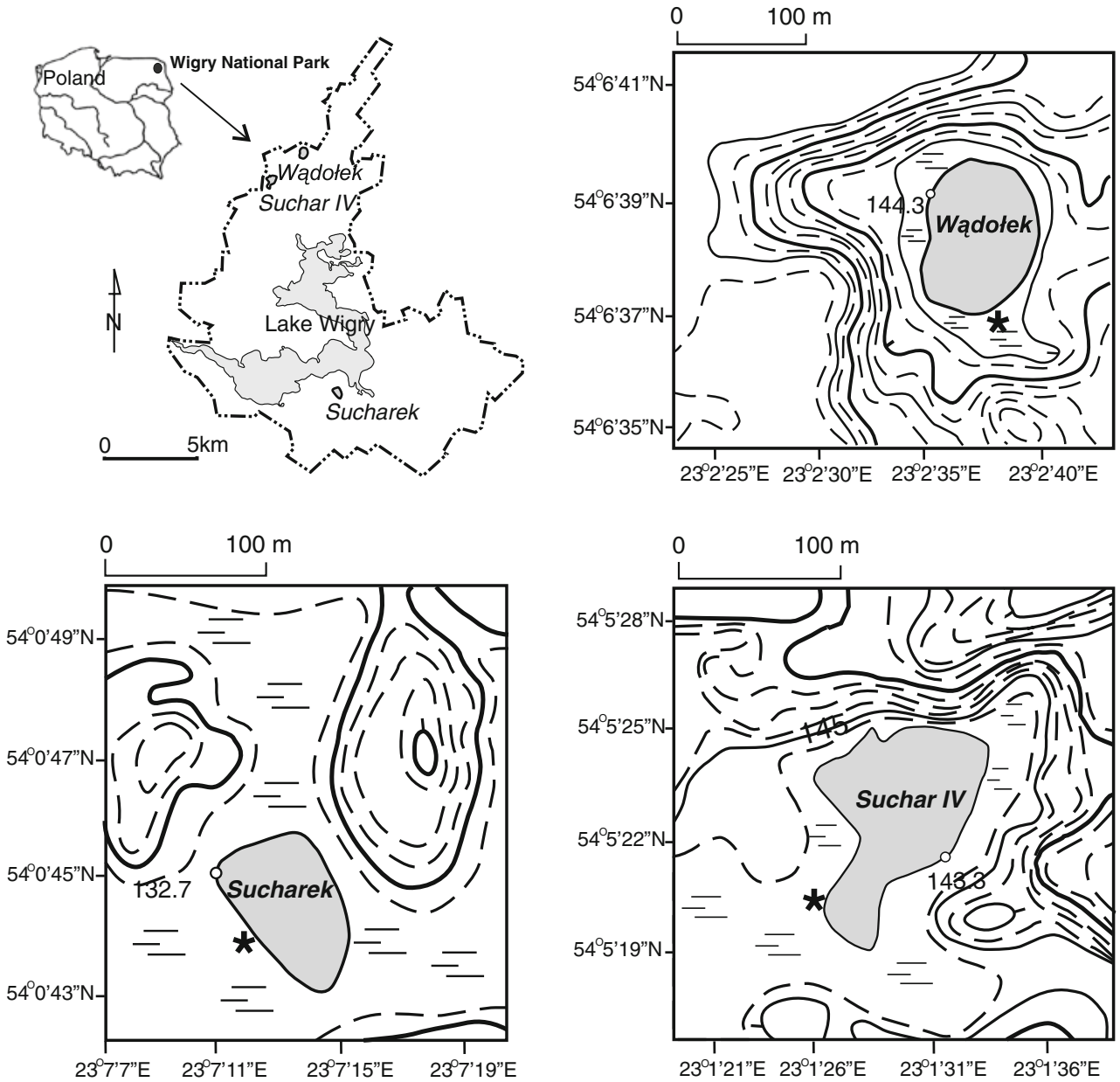

* location of cores $\stackrel{\wp}{143.3}$ spot height $\quad$-..-... park boundary

macrofossils were based on percentage data. Peat units were distinguished according to Tołpa et al. (1967). In $d y$ samples presence of remains was recorded.

The next method was the microscopic analysis of the degree of peat decomposition. This analysis is based on the humus/peat ratio in the sample. According to Obidowicz (1990), peat may be divided into: slightly decomposed (decomposition up to $25 \%$ ), medium decomposed (30-40\%), highly decomposed (45-60\%) and humopeat (65\% and up).
This parameter delivers information about humidity of the mire surface during the past peat forming process. A decrease in the degree of peat decomposition indicates a ground water table rise.

The results were presented as diagrams drawn with the computer program POLPAL (Walanus and Nalepka 1999). Plant macrofossil zones were distinguished (Figs. 2, 3 and 4). They illustrate various stages of vegetation succession and deliver information about palaeoenvironmental changes in the nearest surroundings of the studied humic lakes.

Table 1 Location and parameters of studied lakes (acc. to Górniak (2006))

\begin{tabular}{lllllllll}
\hline Lake & Latitude & Longitude & $\begin{array}{l}\text { Area } \\
\text { (ha) }\end{array}$ & $\begin{array}{l}\text { Max. depth } \\
(\mathrm{m})\end{array}$ & $\begin{array}{l}\text { Shoreline } \\
\text { development index }\end{array}$ & $\begin{array}{l}\text { Catchment } \\
\text { (ha) }\end{array}$ & $\begin{array}{l}\text { Catchment/lake } \\
\text { area ratio }\end{array}$ & $\begin{array}{l}\text { Catchment } \\
\text { character }\end{array}$ \\
\hline Suchar IV & $54^{\circ} 05^{\prime} 22^{\prime \prime} \mathrm{N}$ & $2^{\circ} 01^{\prime} 29^{\prime \prime} \mathrm{E}$ & 0.95 & 8.0 & 1.59 & 68.7 & 72.31 & $\begin{array}{l}\text { Catchment } \\
\text { slope (\%o) }\end{array}$ \\
Wądołek & $54^{\circ} 06^{\prime} 39^{\prime \prime} \mathrm{N}$ & $2^{\circ} 02^{\prime} 37^{\prime \prime} \mathrm{E}$ & 1.09 & 15.0 & 1.28 & 19.4 & 17.79 & Forested \\
Sucharek & $54^{\circ} 00^{\prime} 44^{\prime \prime} \mathrm{N}$ & $2^{\circ} 07^{\prime} 13^{\prime \prime} \mathrm{E}$ & 0.63 & 6.0 & 1.40 & 22.6 & 35.87 & Arable-forested 73 \\
\hline
\end{tabular}




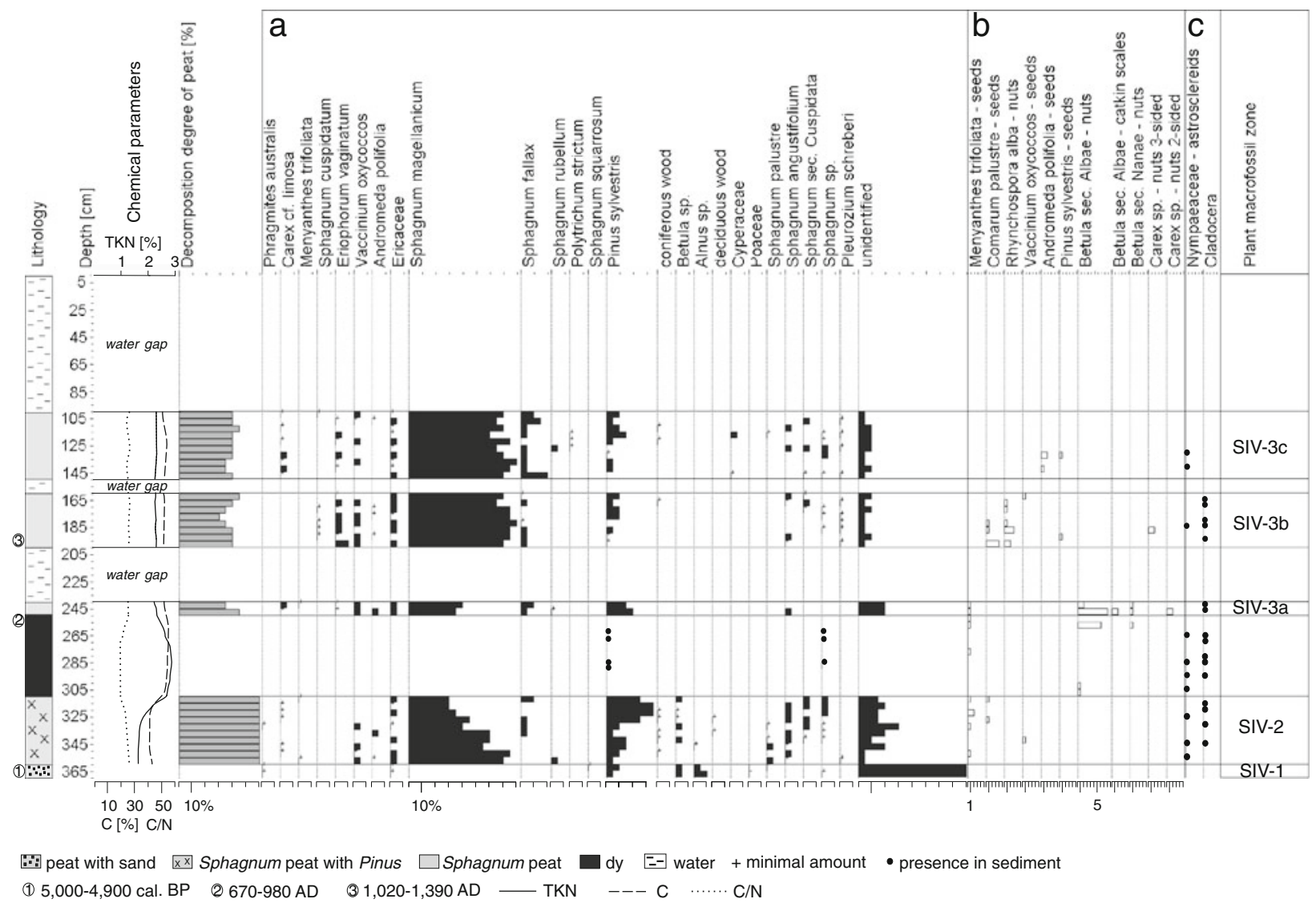

Fig. 2 Lake Suchar IV. Diagram of the macroscopic plant remains, decomposition degree of peat and chemical parameters of sediments. a vegetative remains, b generative remains, $\mathbf{c}$ other remains. Solid line corresponds to TKN, dashed line - to C, dotted line - to C/N

${ }^{14} \mathrm{C}$ samples were prepared by manual selection of plant remains according to Kilian et al. (2000) and dated in the Poznan Radiocarbon Laboratory (Poznań, Poland; Poz), in the Gliwice Radiocarbon Laboratory (Gliwice, Poland; GdA), and in Laboratorium Datowań Bezwzględnych (Skała, Poland; MKL). The radiocarbon age of the samples was calibrated with CalPal 1.5 ver. online software (Danzeglocke et al. 2011) and with OxCal 4.1 online software (Bronk Ramsey 2009). The chronology of the peat profiles was presented according to Mangerud et al. (1974), with calibration of chronozone boundaries (Walanus and Nalepka 2010). The radiocarbon dates are given in detail on Table 2.

The chemical analyses of sediments were based on the quantification of organic carbon content, total Kjeldahl nitrogen (TKN), and on estimation of $\mathrm{C} / \mathrm{N}$ ratio. Sediment samples were dried at $105{ }^{\circ} \mathrm{C}$ after removal of all particulate organic matter greater than $1 \mathrm{~cm}$ in length. For further analyses the sediments were ground to break apart aggregates. Samples were tested for carbonates by treating with $10 \% \mathrm{HCl}$ and observing effervescence. Total organic carbon (C) was determined by incineration of the samples in $550{ }^{\circ} \mathrm{C}$ for $5 \mathrm{~h}$ in a common furnace (Howard and Howard 1990). Total Kjeldahl nitrogen was determined on $0.25-1.0 \mathrm{~g}$ of dry sediment samples according to Bremner and Mulvaney (1982). Organic C and total Kjeldahl N values were corrected to air-dry weight. Lake water $\mathrm{pH}$ was measured using a portable device (Jenway $370 \mathrm{pH}$ Meter).

\section{Results}

The sediment thickness and typologies differed among the cores analyzed. Most of the peat material was comprised of vegetation remains such as vascular plant tissues, leaves, branches, and moss stems. Fruits and seeds were noted sporadically. Aquatic remains such as astrosclereids of Nymphaeaceae and Cladocera and Chironomidae remains were also noted. The deepest sediment samples comprised a peat layer mixed with sand (Figs. 2, 3 and 4).

The two peat units identified in the SIV profile were Sphagnum peat, and Sphagnum peat with Pinus. The peat is moderately and strongly decomposed (Fig. 2). Three macrofossil zones were identified (Fig. 2). In the SIV-1 zone periderm of Pinus sylvestris, Alnus and Betula is recorded (max. 5-10\%). Remains of peat mosses, epiderm of Poaceae, roots of Ericaceae, and epiderm of Phragmites australis are noted in minimal amount. In the SIV-2 zone remains of Sphagnum magellanicum comprise even $75 \%$ of the sediment volume. Periderm and needles of Pinus 


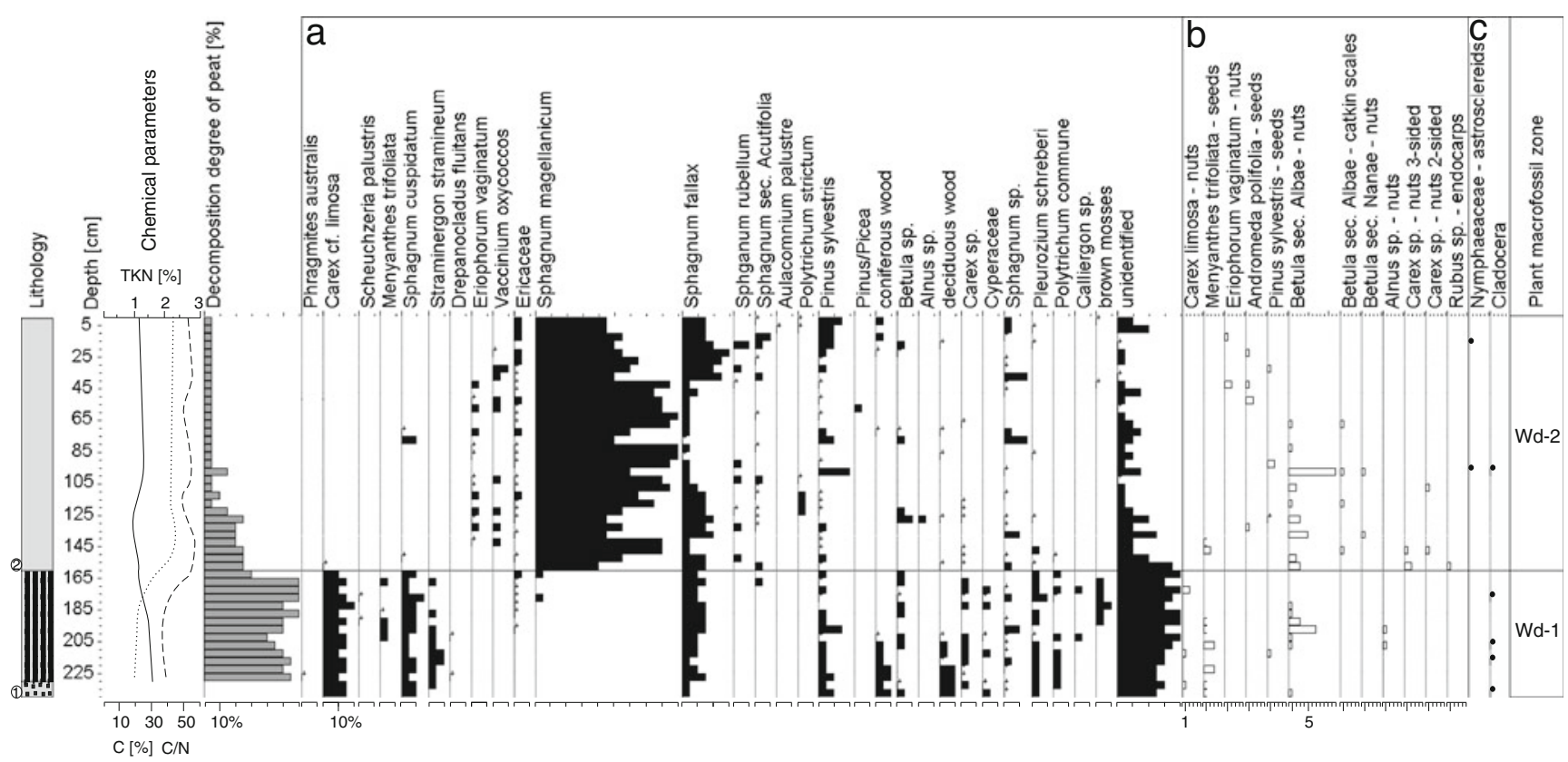

E.:- peat with sand IIII Carex-Sphagnum peat $\square$ Sphagnum peat + minimal amount • presence in sediment

(1) 7,230-7,100 cal. BP (2) 1,953-1,956 AD — TKN

Fig. 3 Lake Wądołek. Diagram of the macroscopic plant remains, decomposition degree of peat and chemical parameters of sediments. a vegetative remains, $\mathbf{b}$ generative remains, $\mathbf{c}$ other remains. Solid line corresponds to TKN, dashed line - to C, dotted line - to $\mathrm{C} / \mathrm{N}$

sylvestris reaches $30 \%$. The last zone (SIV-3) is characterized by the domination of Sphagnum magellanicum (max. $80 \%$ ). The presence of Pinus sylvestris, Ericaceae, Sphagnum fallax, Sphagnum angustifolium, Pleurozium schreberi, and Carex cf. limosa is recorded.
Sphagnum peat and Carex-Sphagnum peat were noted in the $\mathrm{Wd}$ profile, and the degree of the decomposition of the peat was more varied than that in the SIV profile (Fig. 3). Two macrofossil zones were identified (Fig. 3). In the Wd-1 zone vascular plants are represented by radicles of Carex cf. limosa

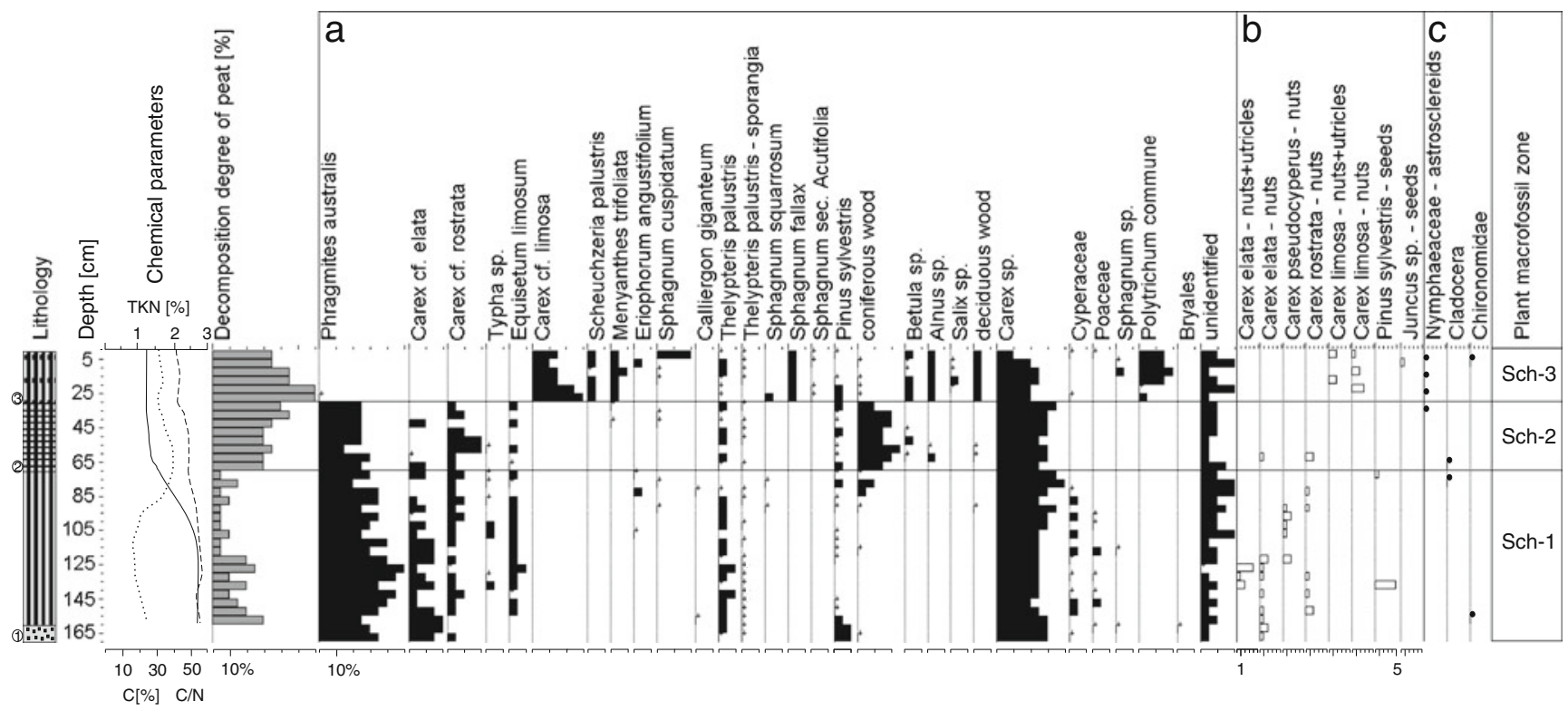

7.:-1) peat with sand 페 Cariceto-Phragmiteti peat

(1) 9,880-9,670 cal. BP $\bigcirc 8,400-8,300$ cal. BP $(3) 2,800-2,580$ cal. BP - TKN --- C …. C/N

Fig. 4 Lake Sucharek. Diagram of the macroscopic plant remains, decomposition degree of peat and chemical parameters of sediments. a vegetative remains, b generative remains, c other remains. Solid line corresponds to TKN, dashed line- to $\mathrm{C}$, dotted line- to $\mathrm{C} / \mathrm{N}$ 
Table 2 Radiocarbon datings from studied profiles

\begin{tabular}{|c|c|c|c|c|c|}
\hline Core & $\begin{array}{l}\text { Sample depth } \\
(\mathrm{cm})\end{array}$ & Sample composition & $\begin{array}{l}\text { Laboratory } \\
\text { number }\end{array}$ & Conv. ${ }^{14} \mathrm{C}$ age & $\begin{array}{l}\text { Cal. year acc. to CalPal } 1.5 \\
\text { (Danzeglocke et al. 2011) } \\
68 \% \text { probability }{ }^{1} \text { and acc. } \\
\text { to OxCal } 4.1 \text { (Bronk } \\
\text { Ramsey } 2009 \text { ) } 95 \% \\
\text { probability }^{2}\end{array}$ \\
\hline \multirow[t]{3}{*}{ Sch } & 29 & Stems of peat mosses & MKL-1796 & $2,620 \pm 70 \mathrm{BP}$ & $2,800-2,580 \mathrm{BP}^{1}$ \\
\hline & 68 & Leaf epiderm of common reed & MKL-1797 & $7,580 \pm 80 \mathrm{BP}$ & $8,400-8,300 \mathrm{BP}^{1}$ \\
\hline & 169 & Leaf epiderm of common reed & Poz-30005 & $8,765 \pm 50 \mathrm{BP}$ & $9,880-9,670 \mathrm{BP}^{1}$ \\
\hline \multirow[t]{2}{*}{$\mathrm{Wd}$} & 239 & $\begin{array}{l}\text { Leaf epiderm of common reed, } \\
\text { stems of mosses }\end{array}$ & Poz-38255 & $6,250 \pm 40 \mathrm{BP}$ & $7,230-7,100 \mathrm{BP}^{1}$ \\
\hline & 153 & Stems of peat mosses & GdA-2382 & $101.29 \pm 0.23 \mathrm{pMC}^{\mathrm{a}}$ & $1,953-1,956 \mathrm{AD}^{2}$ \\
\hline \multirow[t]{3}{*}{ SIV } & 191 & Stems of peat mosses & MKL-1793 & $800 \pm 100 \mathrm{BP}$ & $1,020-1,390 \mathrm{AD}^{2}$ \\
\hline & 255 & Stems of peat mosses & MKL-1794 & $1,210 \pm 70 \mathrm{BP}$ & $670-980 \mathrm{AD}^{2}$ \\
\hline & 369 & $\begin{array}{l}\text { Stems of peat mosses, } \\
\text { grass epiderm }\end{array}$ & Poz- 8253 & $4,405 \pm 35 \mathrm{BP}$ & $5,000-4,900 \mathrm{BP}^{1}$ \\
\hline
\end{tabular}

${ }^{\mathrm{a}}$ The date is modern ( $p M C$ percent modern carbon)

(max. $20 \%$ ), seeds and rhizome epiderm of Menyanthes trifoliata, roots of Ericaceae, wood of coniferous and deciduous trees/shrubs. Mosses, like Sphagnum cuspidatum, Sphagnum fallax, Straminergon stramineum, Pleurozium schreberi, and Polytrichum commune are present. The last zone (Wd-2) is characterized by the dominance of Shagnum magellanicum (max. 90 \%). Sphagnum fallax comprise even $30 \%$.

The threepeat units described in theSch profile were CaricetoPhragmiteti peat, Cariceto-Phragmiteti peat with wood, and Carex-Sphagnum peat. This peat is slightly, moderately, and strongly decomposed (Fig. 4). Three macrofossil zones were noted (Fig. 4). The oldest zone (Sch-1) is characterized by the dominance of Carex radicles (max. $40 \%$ in sample), and remains of Phragmites australis (max. $50 \%$ ). Carex cf. elata comprises even $25 \%$ of the sediment volume. In the Sch- 2 zone radicles of Carex, Carex cf. rostrata and remains of Phragmites australis dominate achieving $35 \%, 20 \%$ and $25 \%$, respectively. Adistinct amount of coniferous wood is noted ( $\max .25 \%$ ). The top zone (Sch-3) is characterized by the dominance of Carex remains (max. $25 \%$ ), and Carex cf. limosa radicles (even $30 \%$ ). Sphagnum fallax, Sphagnum cuspidatum, species of the Acutifolia section, Polytrichum commune, Scheuchzeria palustris, and Menyanthes trifoliata are recorded.

The highest content of organic carbon was noted in the $d y$ sediment from SIV, where it exceeded $54 \%$ (Fig. 2; Table 3), while the lowest (approximately $40 \%$ ) was noted in the CarexSphagnum peat in Wd(Fig. 3; Table3). The TKN contentranged from more than $2 \%$ in $d y$ sediment from SIV (Fig. 2; Table 3) to more than $1 \%$ in Sphagnum peat from Wd (Fig. 3; Table 3). The highest $\mathrm{C} / \mathrm{N}$ ratio (approximately 45 ) was noted in Sphagnum peat from Wd (Fig. 3; Table 3), while the lowest of less than 20 was noted in $d y$ samples from SIV (Fig. 2; Table3). The values of

Table 3 Typology and chemical parameters of sediments

\begin{tabular}{|c|c|c|c|c|c|c|}
\hline Profile & Depth $(\mathrm{cm})$ & Sediment & Mean C (\%) & Mean TKN (\%) & Mean $\mathrm{C} / \mathrm{N}$ & Number of samples \\
\hline \multirow[t]{4}{*}{ SIV } & $100-250$ & Sphagnum peat & 53.61 & 2.27 & 24.73 & 20 \\
\hline & $250-310$ & $d y$ & 54.28 & 2.71 & 19.99 & 12 \\
\hline & $310-360$ & Sphagnum peat with Pinus & 42.53 & 1.74 & 24.32 & 10 \\
\hline & $100-360$ & & 50.14 & 2.24 & 23.01 & 42 \\
\hline \multirow[t]{3}{*}{$\mathrm{Wd}$} & $0-160$ & Sphagnum peat & 53.45 & 1.21 & 45.36 & 32 \\
\hline & $160-230$ & Carex-Sphagnum peat & 40.07 & 1.51 & 25.59 & 14 \\
\hline & $0-230$ & & 46.76 & 1.36 & 35.47 & 46 \\
\hline \multirow[t]{4}{*}{ Sch } & $0-30$ & Carex-Sphagnum peat & 43.80 & 1.36 & 31.53 & 6 \\
\hline & $30-70$ & Cariceto-Phragmiteti with wood & 48.65 & 1.31 & 37.89 & 8 \\
\hline & $70-160$ & Cariceto-Phragmiteti & 52.02 & 2.54 & 22.57 & 18 \\
\hline & $0-160$ & & 48.15 & 1.67 & 30.66 & 32 \\
\hline
\end{tabular}


the chemical parameters of the Sch sediments were intermediate (Fig. 4; Table 3). The lake water $\mathrm{pH}$ in 2011 was: SIV-4.3, $\mathrm{Wd}-5.8$, and Sch-5.5.

The peat-forming processes in the studied lakesides began in different periods of the Holocene. The age of bottom sediments was 5,000-4,900 cal. BP in SIV, 7,230-7,100 cal. BP in Wd, and 9,880-9,670 cal. BP in Sch. The peat moss floating mat of Lake Suchar IV occurred after 670-980 AD, and its presence was confirmed by dating 1020-1390 AD (Fig. 2). In the Wd lakeside bog started to exist about six decades ago (1953-1956 AD) (Fig. 3). In the vicinity of Sch reedswamp vegetation occurred in the Boreal and Atlantic periods. Pine admixture was noted after 8,400-8,300 cal. BP. Sedge-peat moss floating mat started to exist 2,800-2,580 cal. BP (Fig. 4).

The subfossil plant community succession differed in each of the lake shores studied. A rich fen vegetation was only noted in the Sch mire, while that at the Wd and Sch sites comprised moderately poor fen vegetation. The bog phase was noted at SIV and $\mathrm{Wd}$. The following sequences of subfossil vegetation were identified:

SIV shrub communities of fen? (SIV-1 zone) $\rightarrow$ peat moss communities of bog (SIV-2, and SIV-3 zones)

Wd communities of moderately poor fen (Wd-1 zone) $\rightarrow$ peat moss communities of bog (Wd-2 zone)

Sch reedswamp vegetation of rich fen (Sch-1, and Sch-2 zones) $\rightarrow$ communities of moderately poor fen (Sch-3 zone)

\section{Discussion}

All three of the lakes studied have brown waters, but they differ distinctly. Lake Suchar IVexhibited, and still exhibits today, the features of a typical humic lake. Lakes Sucharek and Wądołek should, in light of their past and present qualities, be classified as atypical humic lakes that are on the cusp between dystrophic and eutrophic (Nürnberg and Show 1998). This also means that these lakes can be classified as alloiotrophic (Wetzel 1983), mixotrophic (Williamson and Morris 1999), or humoeutrophic lakes (Górniak 2006; Chmiel 2009; Zieliński et al. 2011). In Estonia, Sweden, and Finland, lakes called dystrophic (humic), semidystrophic, and dyseutrophic are identified (Arst and Reinart 2009). Klavins etal.(2003) describe some Latvian lakes as dystrophic and dyseutrophic, with the latter characterized by higher $\mathrm{pH}$ values.

\section{Lake Suchar IV}

The peat-forming process at the Lake Suchar IV lakeside began in the first half of the Subboreal period (5,000-4,900 cal. BP), and was initiated by shrub communities of birch, alder, and pine (SIV-1) (Fig. 2). The occurrence of shrubs could have resulted from strong surface flow caused by heavy rainfall, what was observed for example by Oświt (1977) in his wetland studies in northeastern Poland. During this part of the Subboreal period, heavy rainfall was noted throughout investigated region (Ralska-Jasiewiczowa and Starkel 1988).

A floating mat comprised primarily of Sphagnum magellanicum (SIV-2 and SIV-3; Fig. 2) was dominant during the development of the mire. Rhynchospora alba, present there, is also representative of low nutrient habitats (Zarzycki et al. 2002), linked to mire pools; the mean height of which appears to be $12-$ $14 \mathrm{~cm}$ above the water table (Mauquoy and van Geel 2007). The floating mat (SIV-3) occurred after 670-980 AD (Fig. 2).

The studied profile reflects distinct changes in hydrometeorological conditions that are representative of this region in the past, and as a result of which both $d y$ sediments and peat accumulated. The peat is moderately and strongly decomposed (Fig. 2), which could have resulted from fluctuations in water levels. However, the occurrence of $d y$ indicates, according to some authors, that the water quality conditions of the lake waters are minimally variable (Więckowski 1978; Górniak 1996). Water gaps (Fig. 2) probably occurred as the result of later water level increases, because they are not a consistent part of the mire (Kowalewski and Barabach 2010).

High TKN content in sediments evidences strong impact of lacustrine ecosystem on the biogeochemistry of the SIV core (Fig. 2; Table 3). Organic matter of lacustrine origin is a source of nitrogen, and the sediments from the SIV core have abundant cladoceran remains, Nymphaeaceae tissues, and Chironomidae larval mouth parts as are reflected in the $\mathrm{C} / \mathrm{N}$ ratio values. The $\mathrm{C} / \mathrm{N}$ parameter is used to determine the domination of autogenic or allogenic sources of organic matter in sediments. The $\mathrm{C} / \mathrm{N}$ ratio for aquatic plants, phytoplankton, and zooplankton is 10 or below, whereas that for terrestrial plants exceeds 10 and can be as high as 45-50 (Meyers 1994; Ji et al. 2005). Algae, phytoplankton, and zooplankton contain large amounts of protein, hence the $\mathrm{C} / \mathrm{N}$ ratio is lower (Krishnamurthy et al. 1986). The sediments from the SIV core include a distinct admixture of autogenic organic matter, which could explain why these sediments had the highest content of nitrogen and the lowest of C/N (Fig. 2; Table 3).

Based on the data presented above, Lake Suchar IV can be classified as a typical humic lake. The substantial impact on its trophic state had also location within a forested catchment area that is large in terms of closed systems (Table 1). The sediment profile studied indicates that the character of this lake did not change for a thousand years. The pine forests covering the area surrounding the lake contribute large quantities of HS (Górniak and Zieliński 2000; Hagedorn et al. 2000), which have and presently continue to reach this lake. Lake Suchar IV has the highest catchment/lake area ratio among the three lakes studied, which is advantageous (for example, Curtis and Schindler 1997), and it also has the highest shoreline development index (Table 1). This indicator describes how the coastline is similar to a circle. A bigger number means that shoreline is more varied and that the 
interface between the water and the surrounding land is more significant (Moses et al. 2011). Both subfossil and contemporary vegetation are typical of humic lakes, while the floating mat comprises two well-developed zones - quaking and firm.

The trophic state of lakes can be determined using the Hydrochemical Dystrophy Index (HDI) described by Górniak (2006). The values of this parameter range from several points for clearwater lakes to more than a hundred for humic lakes. The HDI value of 50 is the minimal values for humic lake classification. The HDI value noted in 2002 for Lake Suchar IV was 104.2, which means that this parameter was more than twofold than the minimal value for humic lakes.

A low chlorophyll a concentration $(14.05 \mu \mathrm{g} / \mathrm{l})$ and the highest DOC content were also noted $(39 \mathrm{mg} / \mathrm{l})$, which is evidence of high HS levels (Górniak 2006). DOC is known to be the principle controlling factor of acidity in humus-rich brown water lakes (Kullberg et al. 1993). Water $\mathrm{pH}$ fluctuated from 3.8 to 6.0 in the 1971-2002 period, but the value of this parameter always indicated strongly acidic conditions, which was confirmed by the $\mathrm{pH}$ value of 4.3 in 2011 .

\section{Lake Wądołek}

Peat accumulation began in the lakeside of Lake Wadołek in the middle of the Atlantic period (7,230-7,100 cal. BP), when rainfall was heavy in the region that is present-day Poland (Ralska-Jasiewiczowa and Starkel 1988). This supported species that tolerate ombrotrophy such as Sphagnum cuspidatum, Sphagnum fallax, Straminergon stramineum, and Carex limosa (Wd-1) (Fig. 3). Conditions in the bog-surface pools were subopitmal for S. cuspidatum (Boatman 1977), while $S$. fallax is often associated with habitats with high humic substance concentrations (Gąbka and Lamentowicz 2008). Straminergon stramineum is typical of moderately rich fens, but is also noted in both rich and poor fens (Hájek et al. 2006). Carex limosa occurs on poor and moderately poor, and acidic and moderately acidic substratum (Zarzycki et al. 2002). Hence, the Lake Wądołek lakeside was likely a moderately poor fen.

Sphagnum magellanicum dominated (Wd-2) the next phase of mire development (Fig. 3). Decreased ground water levels caused the mire to transform into a bog (19531956 AD) supplied by heavy precipitation, which is reflected in the predominance of slightly decomposed peat (Fig. 3). $S$. fallax, ericaceous dwarf shrubs, and Eriophorum vaginatum are evidence of poor habitats. The latter of these species is typical of extremely poor, highly acidic soils (Zarzycki et al. 2002) in which TKN contents and $\mathrm{C} / \mathrm{N}$ ratios exhibit values typical of raised bog peat (Damman 1988) (Table 3).

Based on palaeobotanical analyses, a typical humic phase was identified in the past of Lake Wadokek. Its catchment area was probably forested, which resulted in higher inputs of HS into this lake. Currently, the catchment area is a combination of arable and forested lands (Table 1), where the former comprises about a third of the area. However, the domination of forests is not reflected in the intense DOC supply. This could be explained by the steep slopes of the catchment area (Table 1) which are not advantageous for the accumulation of soil organic matter (for example, Rasmussen et al. 1989). Consequently, dissolved organic matter export from the catchment area was probably much lower than expected, and the DOC content in Lake Wadolek is lower than that in the two other lakes studied (18 mg/l; Górniak 2006). The HDI was only 59.8 in 2002, and, according to Chmiel (2009), when this parameter oscillates around 50, the lake cannot be classified as humic. Moreover, the value of this index fluctuated periodically, which was also noted in a few other lakes in southeastern Poland. The mean $\mathrm{pH}$ value noted in 1986-2002 was high at 6.8 (Górniak 2006), and it was 5.8 in 2011. Additionally, the floating mat is atypical: the first zone is fragmentary, with reedswamp species, and the second zone is absent.

\section{Lake Sucharek}

Decreasing water level in Lake Sucharek was noted at the beginning of the Boreal period $(9,880-9,670$ cal. BP), when lake and mire water level declined in studied region of Poland (Ralska-Jasiewiczowa and Starkel 1988) and also in midEuropean lakes (Magny 2004). Thus, macrophytes could have grown in shallow littoral waters, including species such as Phragmites australis (Björk 2010) that indicates water depths of less than $1 \mathrm{~m}$, which is optimum for this species (Hannon and Gaillard 1997). Tall sedges, like Carex elata, Carex rostrata, and Carex pseudocyperus, as well as Equisetum limosum, Thelypteris palustris, and Typha were present in the lakeside (zones Sch-1 and Sch-2; Fig. 4). Thus, reedswamp vegetation typical of rich fens was present in the Boreal and Atlantic periods, at least, then with pine admixture (see dating 8,400-8,300 cal. BP; Fig. 4). Peat formed beneath the emergent macrophytes from their roots, rhizomes, and leaf bases (for example, Rydin and Jeglum 2008). High values of $\mathrm{C} / \mathrm{N}$ in the Cariceto-Phragmiteti peat (Table 3) could be explained by higher carbon contents in samples with coniferous wood, which were followed by large amounts of lignin (for example, Lamlom and Savidge 2003).

$S$. cuspidatum and $S$. fallax occurred in the decline of the Subboreal period (2,800-2,580 cal. BP), in the last stage of mire development (Sch-3) (Fig. 4), and other taxa associated with bogs and poor fens were also noted, including Carex limosa and Scheuchzeria pulustris, which occur in poor and moderately poor, acidic and moderately acidic substratum (Zarzycki et al. 2002). The last phase of mire development (Sch-3) was characterized by the disappearance of Phragmites australis, Equisetum limosum, and tall sedges. A moderately poor fen formed, and the water level probably did not increase because deciduous trees/shrubs appeared at the mire. Reedswamp vegetation was probably eliminated because of 
changes in the nutrient loads from the catchment area. Strongly decomposed peat at the top could have resulted because of low water level in the lake.

The history of this lake differed from those of the other two lakes studied. Palaeobotanical evidence suggests that Lake Sucharek developed both as a humic lake with signs of eutrophication, and a typical humic lake. The former type of lake formed under the influence of its surroundings that were overgrown by reedswamp vegetation, and a catchment area that was probably not significantly forested. The latter lake type had plant communities linked to moderately poor fens. The HS supply to the lake was probably high at that time, which could have been linked to the extension of pine forest area in the catchment as a result of tree planting following World War II (through the analysis of topographical maps). That is why Lake Sucharek currently resembles contemporary humic lakes, such as Lake Suchar IV.

Some circumstances, however, could portend changes in the near future. The HDI was 82.1 in 2002, which is an intermediate value, whereas high chlorophyll a levels indicate higher trophic levels. Górniak (2006) reported that the mean $\mathrm{pH}$ value from 1994 to 2002 was 6.1, with an extremely high value of 8.1 noted in 1994. Only in 2011 was pH 5.5. DOC content of $28 \mathrm{mg} / \mathrm{l}$ was lower than that in the typically humic Lake Suchar IV. The arable and pasture character of the catchment area plays a significant role in shaping the state of this lake (Table 1).

\section{Problem of Humic Lakes Uniformity}

The terminology for humic lakes must be unified. Already previously there was an assumption that these lakes are not uniform (Drzymulska et al. 2013). In the current study we indicate a need to distinguish the different states of the humic lakes. It was decided that beside typical humic lakes, those exhibiting signs of eutrophication should be referred to as eutrophic-humic lakes. Based on their history from palaeobotanical data, sediment analyses, and current hydrochemical parameters, the following sequences of lake development were identified:

SIV humic lake (SIV-1, SIV-2, SIV-3, and present)

Wd humic lake (Wd-1, and Wd-2) $\rightarrow$ eutrophic-humic lake? (present)

Sch eutrophic-humic lake (Sch-1, and Sch-2) $\rightarrow$ humic lake? (Sch-3) $\rightarrow$ eutrophic-humic lake? (present)

Thus, like clearwater lakes, humic lakes undergo transformation, which confirms the hypothesis of the current study. Usually humic lakes show an oligotrophic phase (OL) in the beginning of their development. However, it is impossible to designate any uniform pattern in the development of brown water lakes because of the complexity of the lake-catchment system. Nonetheless, the transition from a typical humic state $(\mathrm{TH})$ to a eutrophic-humic state (EH) appears to be plausible, as does the reverse:

$$
\mathrm{OL} \rightarrow \mathrm{TH} \leftrightarrow \mathrm{EH}
$$

Our studies demonstrate the lack of uniformity in the developmental history of these three humic lakes and it is therefore vital that further research is conducted in order to recognize the different states of these brown water ecosystems. This will require enhanced investigations of the complex lake-wetland relationships.

Acknowledgments This research was financed by the Ministry of Science and Higher Education in Poland, project nr NN305085135 "History of dystrophic lakes of the Wigry National Park in the light of the Holocene succession of their vegetation". The authors would like to thank the anonymous reviewers for their comprehensive reading of the manuscript and constructive suggestions for its improvement.

Open Access This article is distributed under the terms of the Creative Commons Attribution License which permits any use, distribution, and reproduction in any medium, provided the original author(s) and the source are credited.

\section{References}

Arst H, Reinart A (2009) Application of optical classifications to North European lakes. Aquatic Ecology 43:789-801

Ber A (2009) Budowa geologiczna, geomorfologia i geneza obrzeżenia jeziora Wigry w nawiązaniu do struktur głębokiego podłoża. In: Rutkowski J, Krzysztofiak L (eds) Jezioro Wigry. Historia jeziora w świetle badań geologicznych i paleoekologicznych. Stowarzyszenie Człowiek i Przyroda, Suwałki, pp 13-30

Björk S (2010) The evolution of lakes and wetlands. In: Eiseltová M (ed) Restoration of lakes, streams, floodplains, and bogs in Europe: principles and case studies. Springer, Dordrecht, pp 25-35

Boatman DJ (1977) Observations on the growth of Sphagnum cuspidatum in a bog pool on the Silver Flowe National Nature Reserve. Journal of Ecology 65:119-126

Bremner JM, Mulvaney CS (1982) Nitrogen-total. In: Page AL (ed) Agronomy no. 9, methods of soil analysis. American Society of Agronomy, Madison, pp 595-624

Bronk Ramsey C (2009) Bayesian analysis of radiocarbon dates. Radiocarbon 51:337-360

Brönmark C, Hansson L-A (2005) The biology of lakes of ponds. Oxford University Press, New York

Catling PM, Freedman B, Stewart C, Kerekes JJ, Lefkovitch P (1985) Aquatic plants of acid lakes in Kejimkujik National Park, Nova Scotia; floristic composition and relation to waterchemistry. Canadian Journal of Botany 64:724-729

Chmiel S (2009) Hydrochemical evaluation of dystrophy of the water bodies in the Łęczna and Włodawa area in the years 2000-2008. Limnological Review 9:153-158

Curtis PJ (1998) Climatic and hydrologic control of DOM concentration and quality in lakes. In: Hessen DO, Tranvik LJ (eds) Aquatic humic substances. Ecology and Biogeochemistry. Ecological Studies 133:93-105 
Curtis PJ, Schindler DW (1997) Hydrologic control of dissolved organic matter in low-order Precambrian Shield lakes. Biogeochemistry 36:125-138

Damman AWH (1988) Regulation of nitrogen removal and retention in Sphagnum bogs and other peatlands. Oikos 51:291-305

Danzeglocke U, Jöris O, Weninger B (2011) CalPal-2007online. http:// www.calpal-online.de Accessed 14 April 2011

Davydova N, Servant-Vildary S (1996) Late Pleistocene and Holocene history of the lakes in the Kola Peninsula, Karelia and the northwestern part of the East European Plain. Quaternary Science Reviews 15:997-1012

De Haan H (1992) Impacts of environmental changes on the biogeochemistry of aquatic humic substances. Hydrobiologia 229:59-71

Drzymulska D, Kłosowski S, Pawlikowski P, Zieliński P, Jabłońska E (2013) The historical development of vegetation of foreshore mires beside humic lakes: different successional pathways under various environmental conditions. Hydrobiologia 703:15-31

Evans CD, Jones TG, Burden A, Ostle N, Zieliński P, Cooper MDA, Peacock M, Clark JM, Oulehle F, Cooper D, Freeman C (2012) Global Change Biology 18:3317-3331

Fenner N, Freeman C (2013) Carbon preservation in humic lakes; a hierarchical regulatory pathway. Global Change Biology 19:775-784

Findlay SEG, Sinsabaugh RL (eds) (2003) Aquatic ecosystems: interactivity of dissolved organic matter. Academic, Massachusetts

Freeman C, Evans CD, Monteith DT, Reynolds B, Fenner N (2001) Export of organic carbon from peat soils. Nature 412:785

Gąbka M, Lamentowicz M (2008) Vegetation-environment relationship in peatlands dominated by Sphagnum fallax in Western Poland. Folia Geobotanica 43:413-429

Gąka M, Owsianny P (2006) Shallow humic lakes of the Wielkopolska region - relation between dystrophy and eutrophy in lake ecosystems. Limnological Review 6:95-102

Górniak A (1996) Substancje humusowe i ich rola w funkcjonowaniu ekosystemów słodkowodnych. Dissertationes Universitatis Varsoviensis 448, Białystok

Górniak A (2006) Typologia i aktualna trofia jezior WPN. In: Górniak A (ed) Jeziora Wigierskiego Parku Narodowego. Wydawnictwo Uniwersytetu w Białymstoku, Białystok, pp 128-140

Górniak A, Zieliński P (2000) Influence of catchment characteristics and hydrology on dissolved organic carbon in rivers in northeastern Poland. Verhandlungen des Internationalen Verein Limnologie 27:1142-1145

Górniak A, Jekatierynczuk-Rudczyk E, Dobrzyń P (1999) Hydrochemistry of three dystrophic lakes in Northeastern Poland. Acta Hydrochimica et Hydrobiologica 27:12-18

Hagedorn FH, Schleppi P, Waldner P, Flühler H (2000) Export of dissolved organic carbon and nitrogen from Gleysol dominated catchments - the significance of water paths. Biogeochemistry 50:137-161

Hájek M, Horsák M, Hájková P, Dítě D (2006) Habitat diversity of central European fens in relation to environmental gradients and an effort to standardise fen terminology in ecological studies. Perspectives in Plant Ecology 8:97-114

Hannon GE, Gaillard MJ (1997) The plant-macrofossil record of past lake-level changes. Journal of Paleolimnology 18:15-28

Hansen K (1962) The dystrophic lake type. Hydrobiologia 19:183-190

Hedenäs L (2003) The European species of the Calliergon-ScorpidiumDrepanocladus complex, including some related or similar species. Meylania 28:1-117

Hessen DO (1992) Dissolved organic carbon in a humic lake: effects on bacterial production and respiration. Hydrobiology 229:115-123

Hessen DO, Tranvik LJ (eds) (1998) Aquatic humic substances. Ecology and biogeochemistry. Ecological Studies 133:346

Howard PJA, Howard DM (1990) Use of organic carbon and loss-onignition to estimate soil organic matter in differentsoil types and horizons. Biology and Fertility of Soils 9:306-310
Jasser I (1997) The dynamics and importance of picoplankton in shallow, dystrophic lake in comparison with surface waters of two deep lakes with contrasting trophic status. Hydrobiologia 342(343):87-93

Ji S, Xingqi L, Sumin W, Matsumoto R (2005) Palaeoclimatic changes in the Qinghai Lake area during the last 18,000 years. Quaternary International 136:131-140

Jones RI (1992) The influence of humic substances on lacustrine planktonic food chains. Hydrobiologia 229:73-91

Kankaala P, Huotari J, Peltomaa E, Saloranta T, Ojala A (2006) Methanotrophic activity in relation to methane efflux and total heterotrophic bacterial production in a stratified, humic, boreal lake. Limnology and Oceanography 46:1195-1204

Katz NJ, Katz SW, Kipiani MG (1965) Atlas i oprjedielitjel plodow i semian wstreczajuszczychsja w czetwjerticznych odlozheniach SSSR (Atlas and keys of fruits and seeds occurring in the Quaternary deposits of the USSR). Nauka, Moskwa

Keskitalo J, Salonen K, Holopainen A-L (1998) Long-term fluctuations in environmental conditions, plankton and macrophytes in a humic lake, Valkea-Kotinen. Boreal Environment Research 3:251-262

Kilian MR, van Geel B, van der Plicht J (2000) ${ }^{14} \mathrm{C}$ AMS wiggle matching of raised bog deposits and models of peat accumulation. Quaternary Science Reviews 19:1011-1033

Klavins M, Rodinov V, Druvietis I (2003) Aquatic chemistry and humic substances in bog lakes in Latvia. Boreal Environment Research $8: 113-123$

Kondracki J (1994) Geografia Polski. Mezoregiony fizycznogeograficzne. PWN, Warszawa

Kowalewski G, Barabach J (2010) Struktura osadów zbiornika jeziorno-torfowiskowego Dury V (Bory Tucholskie). Studia Limnologica et Telmatologica 4:65-74

Krishnamurthy RV, Bhattacharya SK, Kusumgar S (1986) Palaeoclimatic changes deduced from $13 \mathrm{C} / 12 \mathrm{C}$ and $\mathrm{C} / \mathrm{N}$ ratios of Karewa lake sediments, India. Nature 323:150-152

Kullberg A, Bishop KH, Hargeby A, Jonson M, Petersen RC (1993) The ecological significance at dissolved organic carbon in acidified water. Ambio 22:331-337

Lamlom SH, Savidge RA (2003) A reassessment of carbon content in wood: variation within and between 41 North American species. Biomass and Bioenergy 25:381-388

Magny M (2004) Holocene climate variability as reflected by midEuropean lake-level fluctuations and its probable impact on prehistoric human settlements. Quaternary International 113:65-79

Mangerud J, Andersen ST, Berglund BE, Donner JJ (1974) Quaternary stratigraphy of Norden, a proposal for terminology and classification. Boreas 3:109-128

Marks L (2002) Last Glaciation maximum in Poland. Quaternary Science Reviews 21:103-110

Mauquoy D, van Geel B (2007) Mire and peat macros. In: Elias SA (ed) Encyclopedia of quaternary science, volume 3. Elsevier, Heidelberg, pp 2315-2336

Meyers PA (1994) Preservation of elemental and isotopic source identification of sedimentary organic matter. Chemical Geology 114:289-302

Miles CJ, Brezonik PL (1981) Oxygen consumption in humic-colored waters by phytochemical ferrous-ferric catalytic cycle. Environmental Science and Technology 15(9):1089-1095

Molot LA, Dillon PJ (1996) Storage of terrestrial carbon in boreal lake sediments and evasion to the atmosphere. Global Biogeochemical Cycles 11:357-365

Moses S, Janaki L, Joseph S, Justus J, Ramakrishnan Vimala S (2011) Influence of lake morphology on water quality. Environmental Monitoring and Assessment 182:443-454

Nauman E (1917) Undersökning öfver phytoplankton och under den pelagiske regionen försiggående gyttja och dy-bildning inom vissa sydoch mellansvenska urbergsvatten. Kungliga Svenska Vetenskapsakademiens Handlingar 56, Stockholm 
Nauman E (1919) Några synpunkter angående limnoplanktons ökologi med särskild hänsyn till fytoplankton (Einige Geschtspunkte sur Ökologie des Planktons). Svensk Botanisk Tidskrift 13:29-163

Nürnberg GK, Show M (1998) Productivity of clear and humic lakes: nutrients, phytoplankton, bacteria. Hydrobiologia 382:97-112

Obidowicz A (1990) Eine Pollenanalytische und Moorkundliche Studie zur Vegetationsgeschichte des Podhale-Gebietes (West-Karpaten). Acta Palaeobotanica 1(2):147-219

Oświt J (1977) Naturalne siedliska torfotwórcze jako podstawa wyróżniania jednostek przyrodniczych. Roczniki Nauk Rolniczych F 79:29-50

Poniewozik M, Wojciechowska W, Solis M (2011) Dystrophy or eutrophy: phytoplankton and physicochemical parameters in the functioning of humic lakes. Oceanological and Hydrobiological Studies 40:22-29

Porcal P, Koprivnjak J-F, Molot LA, Dillon PJ (2009) Humic substances-part 7: the biogeochemistry of dissolved organic carbon and its interactions with climate change. Environmental Science and Pollution Research 16:714-726

Ralska-Jasiewiczowa M, Starkel L (1988) Record of the hydrological changes during the Holocene in the lake, mire and fluvial deposits of Poland. Folia Quaternaria 57:91-126

Rasmussen J, Godbout L, Schallenberg M (1989) The humic content of lake water and relationship to watershed and lake morphometry. Limnology and Oceanography 34:1336-1343

Rodriguéz P, Tell G, Pizarro H (2011) Epiphytic algal biodiversity in humic shallow lakes from the Lower Paraná River Basin (Argentina). Wetlands 31:53-63

Roulet N, Moore TR (2006) Browning the water. Nature 444:283284

Rydin H, Jeglum J (2008) The biology of peatlands. Oxford University Press, Oxford

Sachse A, Babenzien D, Ginzel G, Gelbrecht J, Steinberg CEW (2001) Characterization of dissolved organic carbon (DOC) in a dystrophic lake and an adjacent fen. Biogeochemistry 54:279-296

Salonen K, Kononen K, Arvola L (1983) Respiration of plankton in two small, polyhumic lakes. Hydrobiologia 101:65-70
Satoh Y, Abe H (1987) Dissolved organic matter in colored water from mountain bog pools in Japan. II. Biological decomposability. Archiv für Hydrobiologie 111:25-35

Steinberg CEW (ed) (2003) Ecology of humic substances in freshwaters. Springer, Berlin

Taipale S, Kankaala P, Jones RI (2007) Contributions of different organic carbon sources to Daphnia in the pelagic foodweb of a small polyhumic lake: results from mesocosm $\mathrm{DI}^{13} \mathrm{C}$-additions. Ecosystems 10:757-772

Thienemann A (1922) Biologische Seetypen und die Gründung einer hydrobiologischen Anstalt am Bodensee. Archiv für Hydrobiologie 13:347-370

Tołpa S, Jasnowski M, Pałczyński A (1967) System der genetischen Klassifizierung der Torfe Mitteleuropas. Zeszyty Problemowe Postępów Nauk Rolniczych 76:9-99

Vollenweider RA (1970) Scientific fundamentals of the eutrophication of lakes and flowing waters, with particular reference to nitrogen and phosphorus as factors in eutrophication. O.E.C.D, Paris

Walanus A, Nalepka D (1999) Polpal program for counting pollen grains, diagrams plotting and numerical analysis. Acta Palaeobotanica 2:659-661

Walanus A, Nalepka D (2010) Calibration of Mangerud's boundaries. Radiocarbon 52:1639-1644

Wetzel RG (1983) Limnology. Saunders, Philadelphia

Więckowski H (1978) Bottom deposits in lakes of different regions of Poland. Polskie Archiwum Hydrobiologii 25:483-489

Williamson CE, Morris DP (1999) Dissolved organic carbon and nutrients as regulators of lake ecosystems: resurrection of a more integrated paradigm. Limnology and Oceanography 44:795-803

Zarzycki K, Trzcińska-Tacik H, Różański W, Szeląg Z, Wołek J, Korzeniak U (2002) Ecological indicators values of vascular plants of Poland. Władysław Szafer Insitute of Botany, Polish Academy of Sciences, Kraków

Zieliński P, Ejsmont-Karabin J, Grabowska M, Karpowicz M (2011) Ecological status of shallow Lake Gorbacz (NE Poland) in its final stage before drying up. Oceanological and Hydrobiological Studies 40:1-12 